\title{
Gereja dan Marginalisasi Kaum Perempuan
}

\section{Gelby Eunike Parabang}

Institut Agama Kristen Negeri Toraja

gelbyeunike11@gmail.com

ABSTRAK: Penelitian ini bertujuan untuk meneliti bagaimana Marginalisasi Kaum Perempuan di tengah dunia zaman ini dan sekaligus bagaimana peran gereja tehadap marginalisasi. Allah menciptakan manusia yakni laki-laki dan perempuan. Keduanya memiliki kedudukan yang sama dan tentunya keduanya adalah berharga bagi Tuhan. Manusia yang di ciptakan Tuhan dengan sangat unik. Namun dalam kenyataan yang ada perempuan sering sekali di pandang lemah. Sehingga melalui pandangan ini, kaum perempuan kemudian di pandang tak dapat berbuat apa-apa dan tugasnya hanyalah di dapur. Kaum perempuan kemudian di batasi ruang geraknya dan dibatasi apa yang hendak di lakukannya. Pandangan mengenai kaum perempuan itu lemah masih ada. Namun tak dapat juga dipastikan kebenarannya bahwa marginalisasi terhadap perempuan ini memang sudah tidak ada. Olehnya itu untuk menjelaskan dan mengetahui lebih lanjut tentang hal itu, metode penelitian yang digunakan adalah analisis deskriptif. Adapun Pendekatan yang penulis gunakan dalam penelitian ini ialah Jurnal-buku referensi dan Literature research. Setelah diuraikan secara deskrispi, maka temuan-temuan dalam penelitian ini ialah (I) menjelaskan Marginalisasi (2) menjelaskan Marginalisasi dalam kaitannya dengan Gender (3) Bentuk-bentuk Marginalisasi (4) dan peran Gereja terhadap kaum perempuan

Kata Kunci : Marginalisasi, Gender, Gereja dan Perannya.

\section{Pendahuluan}

Pada dasarnya manusia yang diciptakan oleh Allah baik adanya. Baik laki-laki maupun perempuan diciptakan dalam derajat, harkat, dan martabat yang sama. Realita dalam perjalanan kehidupan manusia, banyak terjadi perubahan peran dan status atas keduanya, terutama dalam masyarakat. ${ }^{1}$ Proses tersebut lama kelamaan menjadi kebiasaan dan agaknya berdampak pada terciptanya perlakuan diskriminatif terhadap 1983).

${ }^{1}$ Ap. Budiyono Hd, Membina Kerukunan Hidup Antar Umat Beriman (Yogyakarta: Kanasinus, 
salah satu jenis kelamin. Dalam hal kewarganegaraan, Kaum perempuan adalah salah satu kekuatan masyarakat yang mempunyai hak dan kewajiban yang sama dalam mengisi kemerdekaan bangsa untuk mewujudkan sistem kehidupan dalam internal suatu negara itu sendiri maupun secara global, yang semakin memberikan penekanan pada aspek demokratisasi, perlindungan hak asasi manusia, lingkungan hidup, serta supremasi sipil. Banyak cara yang dapat digunakan untuk memarjinalkan seseorang atau kelompok. Salah satunya adalah dengan menggunakan asumsi gender. Jika hal tersebut terjadi, maka sebenarnya telah berlangsung proses pemiskinan dengan alasan gender. Diskriminasi gender telah menyebabkan kesengsaraan dan kemiskinan bagi masyarakat terutama bagi kaum perempuan yang lebih sering mengalami diskriminasi gender. Untuk menghindari atau meminimalisir permasalahan ini diperlukan peran semua pihak agar lebih memahami konsep gender dan tidak mengabaikan kepentingan laki-laki maupun perempuan dalam pengambilan suatu keputusan pemerintah. Sehingga korban diskrimansi gender semakin berkurang. ${ }^{2}$

\section{Tujuan dan Manfaat}

Penelitian ini bertujuan untuk meneliti bagaimana Marginalisasi Kaum Perempuan di tengah dunia zaman ini dan sekaligus bagaimana peran gereja tehadap marginalisasi.

\section{Metode Penelitian}

Dengan adanya hal terakait dengan Marginalisasi yang hendak diterapkan dalam masyarakat, untuk meneliti masalah ini penulis menggunakan metode kualitatif deskriptif. Dimana metode ini dilakukan dengan cara menganalisis dan memaparkan secara deskriptif tentang Marginalisasi dan peran Gereja.

\section{Hasil dan Pembahasan}

\section{Pengertian Marginalisasi}

Menurut Kamus Besar Bahasa Indonesia (KBBI), Maginalisasi adalah usaha membatasi; pembatasan. ${ }^{3}$

Marginalisasi adalah sikap perilaku masyarakat atau negara yang berakibat pada penyisihan bagi perempuan dan laki-laki. Marginalisasi lebih kepada peminggiran

\footnotetext{
${ }^{2}$ William-de Vries, Gender Bukan Tabu (Bogor Barat: Center For International Forestry Research, 2006).

${ }^{3}$ Kamus Besar Bahasa Indonesia (Jakarta: Balai Pustaka, 1990).
} 
ekonomi. Marginalisasi juga didasarkan akibat perbedaan gender yang memberi batasan pada peran perempuan. Dalam hal ini Marginalisasi perempuan agaknya lebih sering ditemui. Dimana pada awalnya bahkan dalam Alkitab kaum perempuan tidaklah terlalu di perhitungkan dengan alasan bahwa kaum perempuan itu lemah.

\section{BENTUK MARGINALISASI}

Marginalisasi perempuan berarti menempatkan atau menggeser perempuan ke pinggiran, sebab perempuan dilambangkan sebagai lemah, tidak rasional, tidak berani, sehingga tidak pantas memimpin. ${ }^{4}$ Oleh karena itu marginalisasi terhadap perempuan yang dahulunya hampir mencakup seluruh hal contohnya saja bentuk marginalisasi perempuaan dalam negara dimana pimpinan birokrasi tidak pernah diberikan kepada perempuan walaupun secara teori pimpinan borokrasi ini bisa saja didipimpin oleh perempuan, sehingga melalui hal ini perempuan dianggap sebagai objek alat kontrasepsi daan jikalau perempuam mengambil peran untuk bekerja di sector public maka ini dianggap sebagai ketidaknormalan, hal ini merupakan marginalisasi dalam bentuk kepemimpinan. Adapun bentuk marginalisasi dalam pengambilan keputusan yang terjadi dalam masyarakat dimana setiap dalam proses pembangunan atau apapun itu, perempuan selalu diikut sertakan, akan tetapi perempuan tidak diikut sertakan dalam pengambilan keputusan. ${ }^{5}$

\section{GENDER}

Dalam kehidupan manusia, gender merupakan suatu hal yang mempunyai kedudukan yang penting bagi seseorang dan melalui hal ini dapat menentukan suatu pengelam hidup yang akan dialaminnya. Gender juga dapat menentukan jalan seseorang untuk pendidikan, dunia kerja, dan sektor-sektor public lainya artinya bahwa gender dapat menetukan harapan hidup dan kebebasan untuk bergerak sehingga gender yang menetukan keadaaan seseorang kedapannya. Secara Terminologisgender bisa di defenisikan sebagai harapan budaya terhadap laki-laki dan perempuan. ${ }^{6}$

\section{Analisis Sosial Marginalisasi Kaum Perempuan}

\footnotetext{
${ }^{4}$ A. Nunuk P. Murniati, Getar Gender Volume 1 (Mangelang: IKAPI, 2004).

${ }^{5}$ Hetty Siregar, Menuju Dunia Baru (Jakarta: BPK Gunung Mulia, 2001), 68.

${ }^{6}$ Alfian Rokhmansyah, Pengantar Gender Dan Feminisme : Pemahaman Awal Kritik Sastra, ed. Garudhawaca (Yogyakarta, 2016), 1.
} 
Berhubungan dengan Marginalisasi di dalam masyarakat nampaknya pembatasan ini pernah terjadi. Di masa lampau ruang gerak perempuan memang sangat dibatasi. Sehingga untuk memberikan tempat kepada perempuan sebagai bagian dari warga secara khudus di Indonesia ini sebagaimana halnya dengan para lelaki bukanlah menjadi suatu hal yang mudah. ${ }^{7}$ Banyak diantara masyarakat suku yang ada di Indonesia tidak memberikan hak kepada kaum perempuan untuk mendapatkan waris sama sekali. ${ }^{8}$

Berkembangnya zaman kini perempuan berusaha untuk membebaskan diri dari pola laki-laki. Dalam hal ini bahwa perempuan kemudian mengambil tindakan untuk tidak berada lagi dibawa tatanan yang ditentukan oleh laki-laki. ${ }^{9}$ Mereka semakin sadar bahwa kemanusiaan yang utuh menyangkut baik nilai sosial yang secara tradisional sesuai dengan sifat perempuan dikatakan sesuai dengan laki-laki. Baik dalam kemampuan berfikir. Perempuan agaknya mulai menolak kecenderungan untuk mengkhususkan nilai keperempuanan dalam ruang hidup pribadi saja. Mereka mau menuntut bahwa nila-nilai tersebut terwujud baik dalam menolak tatanan mereka dibawa kekuasaan laki-laki. ${ }^{10}$ Dalam masyarakat kesulitan untuk memberdayakan perempuan itu diakibatkan oleh kurangnya dukungan lingkungan, keterbatasan fasilitas, maupun sistem yang mendukung kemajuan perempuan. Sebab tak dapat dipungkiri bahwa ketidakadilan gender yang terjadi disekitar kita adalah sebuah faktor yang dapat menyebabkan lemahnya kaum perempuan untuk melakukan perubahan. ${ }^{11}$

\section{Refleksi Teologis}

Awalnya Allah menciptakan perempuan dan laki-laki sebagai mahkluk yang setara, keduanya diciptakan menurut citra Allah (Imago dei). Namun jika dalam realitas kesejarahan manusia sangatlah menyimpang dikarenakan munculnya gender yang menyudutkan perempuan sebagai pelayan laki-laki. ${ }^{12}$ Sejauh yang diketahui bahwa kenyataan dalam masyarakat bahwa kaum laki-laki menentukan pola dalam masyarakat sedangkan kaum perempuan berada di bawah laki-laki. ${ }^{13}$ Kodrat laki-laki memang diekenal sebagai pemberani, rasional, produktif serta dapat menghasilkan kekayaan. Sedangkan jika

\footnotetext{
${ }^{7}$ Vries, Gender Bukan Tabu.

${ }^{8}$ Marie Claire Barth Frommei, Hati Allah Bagaikan Hai Ibu (Jakarta: BPK Gunung Mulia, 2006).

${ }^{9}$ Ibid., 12.

${ }^{10}$ Ibid., 13.

${ }^{11}$ Vries, Gender Bukan Tabu, 45.

${ }^{12}$ Siregar, Menuju Dunia Baru, 69.

${ }^{13}$ Frommei, Hati Allah Bagaikan Hai Ibu, 3.
} 
dibandingkan dengan kodrat perempuan adalah lemah lembut, penakut, perasa, reproduktif, suka memelihara apa yang ada dan meneruskan keterampilan lama. Tradisi gereja mengutamakan laki-laki. Bapa-bapa gereja mengikuti pemahaman budaya pada zamannya. Seperti yang dinyatakan oleh Thomas Aquinas dimana ia mengatakan bahwa hanya lakilaki yang sepenuhnya dijadikan menurut gambar Allah, perempuan pada dirinya tidak. Perempuan hanya mencerminkan sejauh mana ia bersama dengan laki-laki. ${ }^{14}$

\section{PERANAN GEREJA}

Gereja hendaknya memberitakan injil dalam masyarakat dan bukan untuk berpolitik dalam hal ini bahwa mencari pengaruh dan juga kuasa melainkan untuk memihak kepada golongan yang menderita serta mengusahakan perbaikan keadaan mereka. Hal ini di dasarkan pada kenyataan bahwa Allah berpihak kepada orang-orang yang tertindas. Menurut C.Ellis Nelson, ia mengatakan bahwa iman yang mengikat berdiam atau bernaung dalam persekutuan orang percaya yang dapat diteladankan bagi anggota-anggota persekutuan yang baru ${ }^{15}$. Tindakan Yesus yang juga mempertahankan hak seorang perempuan. ${ }^{16}$ dalam hal pemberdayaan perempuan gereja hendaknya membuka ruang untuk itu. Maningkatkan peran perempuan dalam pelayanan Dengan demikian, peningkatan peranan kaum wanita adalah proses atau usaha untuk meningkatkan suatu kegiatan yang merupakan tugas utama yang dilakukan oleh kaum wanita. Peningkatan peranan dengan berbagai usaha atau kegiatan yang berdaya guna terhadap seluruh kaum wanita dapat mengembangkan dirinya dalam pelayanan kepada Tuhan.

Peranan laki-laki dan perempuan dalam jemaat atau gereja tentu memiliki faktor atau alasan teologis yang bisa mempengaruhinya. Adapun alasan budaya juga mempengaruhi perbedaan peranan tersebut. Tetapi pada dasarnya, tidak ada orang yang dapat menurunkan atau menjatuhkan satu sama lain karena setiap orang memiliki harkat, harga diri dan martabat yang dianugerahkan Tuhan. ${ }^{17}$

\footnotetext{
${ }^{14}$ Frommei, Hati Allah Bagaikan Hai Ibu.

${ }^{15}$ Rannu Sanderan, "EXEMPLARY Menemukan Kunci Pendidikan Iman Bagi Anak Dalam Keluarga Dan Pembelajaran Agama Di Sekolah" (n.d.).

${ }^{16}$ Frommei, Hati Allah Bagaikan Hai Ibu, 14.

${ }^{17}$ Rannu Sanderan, “Jabatan Gerejawi Dan Peran Perempuan Dalam Pelayanan” (n.d.).
} 


\section{KESIMPULAN}

Marginalisasi perempuan merupakan marginalisasi yang dialami oleh perempuan. Marginalisasi adalah suatu kondisi atau proses yang mencegah individu atau kelompokdari partisipasi penuh dalam kehidupan di bidang sosial, ekonomi, dan politik yang dapat dinikmati oleh masyarakat luas. Marginalisasi Kaum Perempuan memang pernah terjadi namun dapat dijumpai sekarang bahwa pembatasan akan ruang gerak perempuan sudah tidak diterapkan karena kesetaraan gender telah diaspirasikan. Hal itu adalah hal yang sangat baik sebab sebagai ciptaan Tuhan maka ada kesetaraan yang harus selalu di ingat. Perempuan dan laki-laki ada ciptaan Tuhan yang setara. Diciptakan untuk saling melengkapi dan saling menolong.

Dalam hal Marginalisasi jika masih ditemui maka gereja diharapkan dapat berperan aktif dalam penginjilan agar membela orang-orang yang ditindas dan di campakkan seperti yang Tuhan lakukan dalam membela orang-orang yang miskin. Menjadikan Yesus teladan dalam menjalani kehidupan dalam penerapan kehidupan bermasyarakat. Dalam hal ini, menjadi orang yang percaya/ Gereja yang terpanggil hendaknya menjadi terang bagi sesama tanpa memandang segala sesuatunya. 


\section{Daftar Pustaka}

Frommei, Marie Claire Barth. Hati Allah Bagaikan Hai Ibu. Jakarta: BPK Gunung Mulia, 2006.

Gianawati, Nur Dyah. Strategi Bertahan Hidup Buruh Tani Perempuan. Jakarta: Pandiva Buku, 2013.

Hd, Ap. Budiyono. Membina Kerukunan Hidup Antar Umat Beriman. Yogyakarta: Kanasinus, 1983.

Murniati, A. Nunuk P. Getar Gender Volume 1. Mangelang: IKAPI, 2004.

Rokhmansyah, Alfian. Pengantar Gender Dan Feminisme : Pemahaman Awal Kritik Sastra. Edited by Garudhawaca. Yogyakarta, 2016.

Sanderan, Rannu. "EXEMPLARY Menemukan Kunci Pendidikan Iman Bagi Anak Dalam Keluarga Dan Pembelajaran Agama Di Sekolah” (n.d.).

—. "Jabatan Gerejawi Dan Peran Perempuan Dalam Pelayanan” (n.d.).

Siregar, Hetty. Menuju Dunia Baru. Jakarta: BPK Gunung Mulia, 2001.

Vries, William-de. Gender Bukan Tabu. Bogor Barat: Center For International Forestry Research, 2006.

Kamus Besar Bahasa Indonesia. Jakarta: Balai Pustaka, 1990. 